BJHS: Themes 4: 283-291, 2019. C British Society for the History of Science 2019. This is an Open Access article, distributed under the terms of the Creative Commons AttributionNonCommercial-ShareAlike licence (http://creativecommons.org/licenses/by-nc-sa/4.0/), which permits non-commercial re-use, distribution, and reproduction in any medium, provided the same Creative Commons licence is included and the original work is properly cited. The written permission of Cambridge University Press must be obtained for commercial re-use. doi:10.1017/bjt.2019.5 First published online 27 September 2019

\title{
Commentary: ends everlasting
}

\section{JENNY REARDON*}

The question of how collections end raises some of today's and yesterday's most central anxieties about the nature of knowledge, life and justice. It yokes existential questions about endings to empirical questions about the everyday work of science. It cleverly focuses our attention on the constitution of value in scientific work by posing a seemingly paradoxical question: collections end? Collections - at least in the Euro-American West connote things of value. Through aggregating and collecting paintings, books, coins, natural and cultural artefacts, individuals, institutions and nations create things of value - often great value. I mean here not just monetary value, but value in the broader sense. Recall, as the French theorist of science and technology Bruno Latour reminds us, the word 'thing' derives from the Old English, Old Norse word ding, which means a meeting or assembly. ${ }^{1} \mathrm{~A}$ thing, or a gathering, arises around a matter of concern. It is what brings us together into collectivity. ${ }^{2}$ Indeed, the first parliament formed in Iceland in 930 - was named the Althing. As this etymology suggests, what comes to be a thing - and thus an object of our concern and knowledge - is at the heart of who comes to be the collective. As historians of colonialism have documented, collecting can be a way not just of amassing things, but also of fashioning identities and creating empire. Collections generate dominion and purpose. ${ }^{3}$ Given this historic role of collections in the constitution of power, people and places, not surprisingly scholars have attended carefully to their creation. What reasons, however, do we have for asking how collections end? Why should we ask this question now?

\footnotetext{
"Science \& Justice Research Center, University of California, Santa Cruz, 1156 High Street, Santa Cruz, CA 95064, USA. Email: reardon1@ucsc.edu.

I would like to thank Boris Jardine and Jenny Bangham for their imagination and vision that let to How Collections End. I also thank the editor of BJHS Themes and Lawrence Chua for their astute readings of an earlier draft. Finally, my gratitude to Jenny Bangham for final edits and ensuring that the writing of this essay came to a successful end. Writing of this peice was supported by a residency at the Freiburg Institute of Advanced Study.

1 Bruno Latour, 'From realpolitik to dingpolitik', in Bruno Latour and Peter Weibel (eds.), Making Things Public: Atmospheres of Democracy, Boston: MIT Press, 2005, pp. 14-44.

2 As the introduction to this volume notes, the word 'collection' derives from the Latin colligere - 'to gather together'.

3 As Maya Jasanoff details, the taking and returning of trophies - such as the 'Somnath gates' - played major roles in the negotiation of the ends and purposes of the British Empire. Maya Jasanoff, Edge of Empire: Lives, Culture, and Conquest in the East, 1750-1850, London: Fourth Estate, 2005, pp. 312-316.
} 


\section{4}

Jenny Reardon

Of course, collections always have been subject to endings - whether by decay, defeat or dispersion. ${ }^{4}$ Yet today the problem of their end feels pressing. We live in a new age of accumulation, this time motivated by a desire to acquire power not through the accession of colonial territories, but through the aggregation of data. Built into this transformation of the object of collection from bounded material thing to seemingly infinite data is the question of limits - that is, of endings. In a world where fish in the sea decline, trees on the land burn and oil in the earth dries up, data is the one thing that seems to proliferate. Consider genomic data. Sequencing one human genome generates 3 billion bits of data for a haploid sequence. Sequencing a full diploid - mother and father - generates 6 billion bits, and upwards of 100 billion if you want that sequence data to be accurate. This is just one human genome. To sequence the billions that genome scientists imagine brings us into orders of magnitude of data never before imagined.

Not only does the quantity of genomic data seem to have no end, but the value attending it also appears limitless. To wit, consider Rosario Isasi's end to her Nature review of The Postgenomic Condition: 'The human genome has ineffable value.'5 The value of genomic data, she argues, lies beyond the limit of expression in words. ${ }^{6}$

Yet while for many the seeming limitlessness of data has been cause for euphoria even quasi-religious proclamations about ineffability and the secret of life - for others it has become a central ethical and political problem. Data collection, many now argue, must have an end. This end must not just constitute a physical limit, but also create moral and ethical value. As recent scandals rocking Silicon Valley demonstrate, it is not enough to create newer, faster and cheaper ways of collecting, storing and circulating data. While genome and data scientists are correct that alone our data means very little - it gains value only in aggregation - endless aggregation also may cause a crash in value. In the wake of the spring 2018 revelation of data breaches, Facebook's value dropped by 58 billion dollars. ${ }^{7}$

Where and how do we end the collection of data? When one places information on Facebook and marks it as 'public', does that mean that it can be collected and aggregated for any purpose? Facebook recently decided 'no' ${ }^{8}$ There must be moral and ethical ends to its use. Must there also be an ethical end to its financial value? When Mark Zuckerberg is worth 66.5 billion dollars, is that too much? ${ }^{9}$ When the British government collects 7,753,000 samples from its citizens, has that gone too far (see Skinner and Wienroth, this issue)? How much aggregation of wealth and DNA, how much

4 The defeat - or at least retreat - of colonial powers has left the status of many collections in question. The Parthenon marbles are the most famous example, but they are by no means unique.

5 Rosario Isasi, 'Genomics and justice', Nature (2017) 551, pp. 296-297.

6 Its expression in dollars and cents is more tangible. Illumina, a company that controls the vast majority of the genome sequencing market, is currently worth $\$ 46.8$ billion, and is on the Forbes list of Growth Champions. See www.forbes.com/companies/illumina, accessed 10 April 2018.

7 Josh Martin, 'The week Facebook's value plunged \$58bn,' BBC, 23 March 2018, at www.bbc.com/news/ business-43517995.

8 Matt Burgess, 'Facebook fixed a massive data scraping issue it said wasn't a problem', Forbes, 5 April 2018, at www.wired.co.uk/article/facebook-news-data-scraping-mark-zuckerburg.

9 See www.forbes.com/profile/mark-zuckerberg, accessed 10 April 2018. 
growth in inequality and erosion of privacy, is too much? These questions define the zeitgeist of our day.

For many, collection has become too easy, too fast, too lucrative. In so doing, it has threatened not just the enterprise of collection, but also the dominant practices and institutions of collective life. As I write, the hashtag \#deletefacebook circulates widely. Calls for Mark Zuckerberg to quit Facebook make headlines. ${ }^{10}$ Alternative systems for storing and collecting things of value - whether it be personal information, money or fruit flies are sites of enormous cultural and economic investment, hopes and dreams. BitCoin promises both freedom from government surveillance and control, and new sources of wealth. Drososhare - an online method for geneticists to obtain fruit fly strains - imagined increased capacities for sharing and fewer constraints on knowledge production (Bangham, this issue).

Yet while questions about the proper means and ends of collecting may feel newly relevant, collections have long posed these questions that are at once ontological, ethical and epistemic. ${ }^{11}$ What are things in this world, entities of value that should be collected such that they might endure beyond the ends of our mortal lives? Who is the 'we' who might rightly collect? As shown in the stories collected here, things do not exist out in the world ready to be plundered by intrepid collectors. They must be made and remade. Central to these laborious efforts are care, community and communication. If any of these go awry, collections can and do end. By way of exploring some of the key themes of this issue, I briefly reflect on the lessons learned about each through reading together the assembled papers for this special issue of BJHS Themes.

\section{Handle with care}

The 'black-bellied dew lover' Drosophila melanogaster is a 'frail and pampered' creature, writes Jenny Bangham in her fascinating exploration of the living infrastructures of genetics. These fruit flies are the fabled, first model organism of genetics. What most historians of science will know about them is how they travelled in the celebrated moral economies described in Robert Kohler's now classic Lords of the Fly. ${ }^{12}$ However, Bangham's new historical work reveals the vitality of the labour of the less celebrated workers in the stockrooms. Around the world (although primarily in Bloomington, Indiana) dozens of technicians and scientists work day and night to keep alive tens of thousands of strains of fruit flies. Unlike the worm C. elegans, or human embryos, one cannot freeze flies and thaw them when needed. You must keep them alive. This is no easy task. These tiny, barely visible (two millimetres long) beasts require their own chefs. Workers at the Drosophila Species Stock Center (Cornell) regularly

10 Shona Ghosh, 'Mark Zuckerberg should quit as Facebook chairman, according to shareholder with a $\$ 1$ billion stake', Business Insider, 3 April 2018, at https://nordic.businessinsider.com/zuckerberg-quit-aschairman-facebook-shareholder-2018-4.

11 On the join of the ethical, epistemic and ontological see Karen Barad, Meeting the Universe Halfway: Quantum Physics and the Entanglement of Matter and Meaning, Durham, NC: Duke University Press, 2007.

12 Robert Kohler, Lords of the Fly: Drosophila Genetics and the Experimental Life, Chicago: The University of Chicago Press, 1994. 
prepare each day eleven different recipes of the desired flavors, from 'Applesauce' to 'Saguaro Potato' to 'Senita Cactus'. This food, in turn, must be consumed under the right conditions. Raise or lower the temperature or air pressure by a fraction and the flies will stop producing eggs. The strain could end.

Fragility - and the attendant fear that things may come to an end - is one feature of the things at the heart of many of the stories collected herein. In Ann Kakaliouras's story, the precarity of ancient human remains takes centre stage. Is it the technological challenge of preservation - and the correlated experience of 'progress' it offers - that generates the 'inter-est' in these very old skeletons? ${ }^{13}$ Or is this care and concern a more existential matter? Is it a response to the fear and pain of loss, as in Boris Jardine's story of Francis Maitland Balfour, the young biologist tapped to be Darwin's successor before losing his life on Mont Blanc (Jardine, this issue)?

Whatever the reason for the deep affection that often attends the preservation of collections, the stories in this issue make clear that people do not care for collections primarily for economic remuneration. In Bangham's story, we meet a stock keeper who knew nothing about fruit flies when first hired, but after over thirty years of tending to them confessed that she will 'still worry about them' when she retires. These flies - in sickness and in health - have shaped their caretakers. Bangham herself reports having lost many weekends to collecting 'virgins' from pupating vials (Bangham, this issue). For the stock keeper she interviews, connection to the flies endures beyond the contractual end of a job. The bonds are enduring, forged as they are through the entangled intimate processes of knowing and caring. For such small creatures, flies contain an enchanting amount of diversity. They can be chubby, humpy or hairy; fluted, jaunty or jagged. ${ }^{14}$ As we come to know this diversity, they become, in the words of Maria Puig de la Bellacasa, matters of our care. ${ }^{15}$

\section{Making collections, making collectivities}

Yet who are we who care? Making collections, our authors show us, entails making collectivities. As we collect flies, bones and beans, we collect ourselves. We fight to preserve the histories and labours that make us up. We passionately work to keep our connection to Grandpa Ott through preserving the seeds of his tomatoes we grew up eating, his morning glories we smelled fresh at our kitchen table in spring. Helen Curry's essay beautifully entangles these poignant and pragmatic dimensions of collecting as they interweave in the stories of saving seeds. In a seed lies the potential for life everlasting. To save seeds is to save lives and life forms: to stave off the Green Revolution; to save ties to the old country, Bavaria, where Grandpa Ott was born (Curry, this issue). We are made up by these diasporic pasts and beloved grandparents.

13 Hannah Arendt coined 'inter-est' to call attention to the word's etymological meaning: that which lies between us. Hannah Arendt, The Human Condition, Chicago: The University of Chicago Press, 1958 [1998], p. 182.

14 'Drosophila mutant phenotypes', at www.cgslab.com/phenotypes.

15 Maria Puig de la Bellacasa, 'Matters of care in technoscience: assembling neglected things', Social Studies of Science (2011) 41, pp. 85-106. 
We are also made up by empire and dominion. As historians of the British Empire have shown, collectors played pivotal roles in creating the symbols that legitimated colonial rule. Notably, the Rosetta Stone became an enduring emblem of Britain's victory over France in the Napoleonic Wars. ${ }^{16}$ Today the secretary general of Egypt's Supreme Council of Antiquities, Zahi Hawass, demands that it leave the British Museum and return to Egypt. Once again this piece of granodiorite stele lies at the heart of a battle over the proper constitution of power and social order, this time in post-colonial Europe and a post-revolution Egypt. ${ }^{17}$

As the authors in this volume make clear, collectors of objects of scientific inquiry play a similar pivotal role in the constitution of power. While theirs is ostensibly the power to know, it is also the power to live. How should we know the world? How should we live in it? Emma Kowal's fascinating story of the Aboriginal objects collected by Walter Baldwin Spencer, and the statue collected of him, reveals how these questions never part company. Spencer believed that his collection of Aboriginal objects would help ensure the ongoing life of Aboriginal peoples and their cultures. Kowal's account part history, part self-ethnography - follows the shifting fates both of these objects and of the narratives attached to them. By the time Kowal became a student at university in the late 1990s, post-colonial scholars understood Spencer to be an anthropologist who played a central role in eliminating the native. Inspired by this work, Kowal and her fellow student activists created 'Baldwin Spencer was a racist' stickers, and affixed them to the university building named in Baldwin's honor.

In the same time period, curators at the Museum Victoria, in consultation with Aboriginal peoples, decided to subject Spencer to his own medicine, placing a statue of him in a museum display case to serve as a prop for an exhibit. Fates changed once more fifteen years later when, in 2012, an all-Indigenous-designed exhibit removed Spencer from public display. The Indigenous designers of this exhibit argued that Spencer had no place in the museum. Many museum staff felt differently. Despite being just a 'prop' and not a proper artefact, they retained Spencer on a trolley - first in the receipt room where new items arrive, and then in the restricted room where the museum secures ceremonial objects not to be seen by a general audience. Museum workers could not let go, Kowal explains, because the display of Spencer in a case had for years held together a particular kind of white anti-racist subjectivity. 'If Spencer is in the case and we are outside the case looking at him', Kowal writes, 'then we cannot be Spencer. The glass between us promises we are different - progressive, anti-racist, post-colonial or even decolonizing' (Kowal, this issue).

The practices and objects of collection congeal ideals of truth, identity and justice. When they end, in an important sense, those ideals also end. Not surprisingly, then, ending collections is often contentious and hard, as borne out in Ann Kakaliouras's story of the repatriation of Kennewick Man/the Ancient One. This skeleton found surfaced by the forces of erosion on the banks of the Columbia river in 1996 became the

16 Jasanoff, op. cit. (3), 220.

17 Jack Shenker, 'Egypt's man from the past who insists he has a future', The Guardian, 19 May 2011, at www.theguardian.com/world/2011/may/19/the-new-egypt-100-days-on. 
object of heated debates about the origins of the first humans in North America. Based on measurements of craniofacial morphology, physical anthropologists argued that the skeleton was not Native American. They coined a new term, 'Palaeoamerican', to replace 'Palaeoindian' as the descriptor of first peoples of the Americas. On the basis of their measurements and the new concept of the Palaeoamerican, Native peoples were denied their request to repatriate Kennewick Man/the Ancient One.

In 2014 and 2015, however, geneticists published findings of palaeogenomic research that suggested that Kennewick Man/the Ancient One was related to contemporary Native people. Subsequently the skeleton was repatriated and reburied at an undisclosed site on the banks of the Columbia river in Oregon. ${ }^{18}$ Many physical anthropologists, archaeologists and museum curators fiercely resisted the repatriation. The passage of the Native American Graves Protection and Repatriation Act led them to believe that their academic disciplines might be shut down. These fears of their own end, Kakaliouras argues, were overblown. Stories of endings are not so clear-cut. There is not just one ending. Indeed, in the case of the Palaeoamericans, there were many endings. Some skeletons of the so-called Palaeoamericans might have been lost, but others were retained. Some might have been lost, but not before scientists had a chance to study them and take measurements. In the meantime, archaeology, physical anthropology and museum studies continued on, innovating new theories, technologies and ethics. Paleoamericans, too, Kakaliouras suggests, will live on as long as there are those who believe in and speak about them.

\section{Commune with the dead}

Kakaliouras's many endings invite us to ask ontological questions about collections. What are collections? How much do they depend on the material artefacts, the skeletons? To what extent do these skeletons have ghostly dimensions, taking up residence in words, symbols and haunting stories?

The power of words and symbols for the constitution of collections is powerfully illustrated in Bangham's account of the naming of different strains of Drosophila. Names, she argues, are tools for doing particular things valued by a community. They must not be too long, or they will not fit on a vial. They must not be too short, or they will not convey enough information. Getting this right is vital. More than the flies themselves, these symbols are what geneticists handle on a day-to-day basis. Drosophila are small and unremarkable. It is hard to see them or do anything with them without labels and documentation. 'Without ... the means to communicate that information', Bangham writes, 'a stock is functionally useless'. But names are notoriously hard to standardize. Names and symbols often shape how scientific objects can be studied, and by whom,

18 Jennifer A. Raff and Deborah A. Bolnick, 'Paleogenomics: genetic roots of the first Americans', Nature (2014) 506(7487), pp. 162-163; Morten Rasmussen, Martin Sikora, Anders Albrechtsen, Thorfinn Sand Korneliussen, J. Víctor Moreno-Mayar, G. David Poznik, Christoph P.E. Zollikofer, Marcia S. Ponce de León, Morten E. Allentof, Ida Moltke, Hákon Jónsson, Cristina Valdiosera, Ripan S. Malhi, Ludovic Orlando, Carlos D. Bustamante, Thomas W. Stafford Jr, David J. Meltzer, Rasmus Nielsen and Eske Willerslev, 'The ancestry and affiliations of Kennewick Man', Nature (2015) 523, pp. 455-458. 
and at times this has led to a conflicting mass of nomenclatures in genetics. Thus, as geneticists themselves report, they 'would rather share a toothbrush than a nomenclature' (Bangham, this issue).

What is true for flies in this instance is also true for humans. When, in the first years of this new millennium, scientists wanted to create stocks of different kinds of human DNA in order to study human genetic variation - an effort that became known as the International Haplotype Map Project - they needed a nomenclature to organize their collection. Yet unlike with flies, where naming is often a whimsical affair - superman, kryptonite and yippee today all don different strains of drosophila - naming of humans is a more serious, sometimes deadly, affair. ${ }^{19}$ I give but one example. In 1942, Jan Czekanowski - considered the founder of 'Polish anthropology' and known for using statistical techniques to argue against the idea of distinct races - successfully argued that the Karaims who lived in the south of Poland were 'Turkish', not 'Jewish'. Reportedly, this act of naming saved the Karaims from being sent to the camps. ${ }^{20}$ Recognizing these grave histories, organizers of the HapMap initially decided to give over the power to name DNA to 'the communities' from whom the DNA was collected.

Given the attachment to naming practices Bangham documents, perhaps it shall not surprise that many genome scientists objected to this decision. The 'communities' consulted came up with names that reflected their identities and histories. For example, one in Southern Europe chose the name 'Traditionally Red': red for blood, red for wine, and red for left-wing. The scientists rejected this and all the other names they proposed. As a leader of the initiative explained, 'The scientists wanted to have a name so they can go into the computer and pull them out and know what they are, which means that they cannot be three paragraphs with ten footnotes. It's got to be short and content rich.'21

In the end, the scientists prevailed. Today HapMap samples are categorized by threeletter codes. DNA collected from the 'Yoruba in Ibadan, Nigeria' are known as 'YRI'. DNA collected from 'Japanese in Tokyo, Japan' is JPT. Organizers of the HapMap explicitly instructed researchers not to refer to the YRI as 'Africans' or the 'JPT' as 'Asian'. HapMap leaders believed that the use of the 'precise' three-letter codes combined with the jettisoning of categories associated with race would protect against use of the HapMap data for discriminatory purposes. Precise scientific nomenclature, they believed, could ward off the ghosts of eugenic pasts.

This strategy of endeavouring to contain the meaning of collections through prohibiting the use of certain words to label collections is not unique. Notably, the German Code of Crime Procedure, Paragraph 81E (1997), states that it is illegal to predict the biogeographical ancestry of the DNA of an unknown person. In Germany, where the histories of eugenics and Nazi race science still loom large, currently there are public debates

19 Michael R. Seringhaus, Philip D. Cayting and Mark B. Gerstein, 'Uncovering trends in gene naming', Genome Biology (2008) 9, p. 401.1-401.4.

20 Miroslaw Krzyśko, 'Jan Czekanowski: anthropologist and statistician', Folia Oeconomica (2009) 228, pp. 22-32.

21 Jenny Reardon, The Postgenomic Condition: Ethics, Justice, Knowledge after the Genome, Chicago: The University of Chicago Press, 2017, p. 84. 
about how and whether the state should collect DNA. The use of the term Rasse - the German word for 'race' - is taboo, and racial categories are strictly forbidden as labels for DNA. 22

Today these efforts to regulate the language used for collecting and analysing DNA face resistance. In a recent prominent opinion piece in the New York Times entitled 'How genetics is changing our understanding of race', population geneticist David Reich argued that the American people should take 'their heads out of the sand' and recognize that DNA analysis shows that there may be 'substantial biological differences among human populations' that 'correlate with many of today's racial constructs'. ${ }^{23}$ 'Race', in short, should not be banned from public and scientific discourse about genomics.

While that op-ed came as a shock to many inside and outside the academy, it should come as no surprise to the historian of the life sciences. ${ }^{24}$ For decades, race was the central object of study in anthropology. ${ }^{25}$ It did not suddenly come to an end when, in the 1990s, some human population geneticists attempted to respond to accusations that their work was racist by arguing that genomics would demonstrate the meaninglessness of race. ${ }^{26}$ Indeed, when the HapMap project forbade the use of categories associated with race, many continued to use these categories, criticizing the HapMap policy as misguided political correctness. ${ }^{27}$ Even in Germany there is today a move to overthrow the ban of associating DNA with ancestry. ${ }^{28}$ This is not a reintroduction of the German Rasse, but in the language of Kakaliouras, it is a push to introduce a "quasi-racial classificatory scheme shrouded in the language of "population ancestry", (Kakaliouras, this issue).

This history of racial categories in science makes it clear that one may ban words, but one does not so easily exorcize ghosts. Collections cannot be stripped of meanings by the mere stripping of words. Meaning-making - as the flies, the beans and the bones described herein make evident - entails a choreography of words, time and affect, the

22 Turna Ray, 'Push for forensic DNA phenotyping, ancestry in Germany raises discrimination concerns', Genome Web, 4 May 2018, at www.genomeweb.com/policy-legislation/push-forensic-dna-phenotypingancestry-testing-germany-raises-discrimination.

23 David Reich, 'How genetics is changing our understanding of race', New York Times, 23 March 2018, at www.nytimes.com/2018/03/23/opinion/sunday/genetics-race.html.

24 Many I have spoken to since have expressed amazement. Did not genomics, as the New York Times reported at the turn of the millennium, prove that race is not biologically meaningful? For a history of these claims about race and genomics see Jenny Reardon, Race to the Finish: Identity and Governance in an Age of Genomics, Princeton, NJ: Princeton University Press, 2005.

25 George Stocking, Race, Culture, and Evolution: Essays in the History of Anthropology, Chicago: The University of Chicago Press, 1968.

26 Even those who argued against the biological meaning of 'race' - most notably the prominent human population geneticist Luca Cavalli-Sforza - only argued that the socially constructed notion of race used in society was not meaningful. Race could be used if defined using a proper scientific - precise - approach. This is an old position, dating back to the UNESCO Statements on Race. See Reardon, op. cit. (24).

27 Jenny Reardon, 'Democratic mis-Haps: the problem of democratization in a time of biopolitics', BioSocieties (2007) 2, pp. 239-256.

28 Marie Bröckling, 'Warum die Ausweitung der polizeilichen DNA-Analyse auf äußere Merkmale problematisch ist' (8 February 2018), at https://netzpolitik.org/2018/34c3-warum-die-ausweitung-derpolizeilichen-dna-analyse-auf-aeussere-merkmale-problematisch-ist. 
living and the non-living. The world, as Donna Haraway has so powerfully argued, is not made up of words and things, but of material-semiotic actors. ${ }^{29}$ Responding to the trouble of collections today - knowing what to keep, what to discard and how to collect anew - requires learning to see and respond to these richer relations.

\section{A proper ending?}

The constitutional importance of endings is so self-evident as to be the source of many a trite saying. For some things to live on, some things must end. All good things must come to an end. Yet knowledge about endings remains surprisingly understudied, and capacities to respond to them - that is, to response-ably end - remain remarkably underdeveloped. ${ }^{30}$ In the chambers of the American Congress in the spring of 2018, these failings became a matter of political theatre. When pressed on how he would ensure that Facebook users' data would come to proper ends, frequently Facebook CEO Mark Zuckerberg answered, 'My team will get back to you.' 31 How this performance would end - one that pit the power and authority of social-media titan Facebook against one of the world's great nation states - was hard to foresee. ${ }^{32}$ However, as we cast our eyes to the past in the pages of this issue, a keen reader will discover hints. Despite the renegade pastiche of the digerati - their fetishization of the future and disdain for the past - they do not escape the longue dureé, the ongoing constitutional significance of collecting. ${ }^{33}$ What we can know, how we can know, and who can know - and thus who may live and how - hinge on how and what we collect, and on capacities to decide their proper ends.

29 Donna Haraway, 'Situated knowledges: the science question in feminism and the privilege of partial perspective', Feminist Studies (1988) 14, pp. 575-599.

30 The language of response-ability derives from Karen Barad and Donna Haraway. See Barad, op. cit. (11); Donna Haraway, When Species Meet, Minneapolis: University of Minnesota Press, 2008.

31 Through its recursion, Zuckerberg's answer created a new source of unendingness. I would like to thank Lawrence Chua for this insight.

32 Sheera Frenkel and Tiffany Hsu, 'Mark Zuckerberg has a lot of homework to do', New York Times, 11 April 2018, at www.nytimes.com/2018/04/11/technology/zuckerberg-congress-promises-facebook.html, accessed 13 April 2018.

33 A portmanteau of literati and digital. 